Assiut Vet, Med. J. Vol. 50 No. 101 April 2004

Istanbul University, Fac of Vet Med.

Dept, of Biochemistry, Avclar, Istanbul, Turkey.

\title{
EFFECT OF DIETARY VITAMIN E \\ ON PERFORMANCE AND EGG QUALITY \\ OF DIFFERENT INDUCED MOLTING METHODS \\ OF LAYING HENS \\ (With 5 Tables)
}

By

\author{
GÜLHAN TÜRKMEN; KEMAL ÖZTABAK \\ and HASRET YARDIBI. \\ (Received at 25/2/2004)
}

\section{SUMMARY}

Recycled Isabrown hens, by the use of low sodium diet treatments were compared to hens with feed withdrawal forced-molt procedure and an untecycled control. The objective of the present study is to assess the effect of vitamin $\mathrm{E}$ on productivity and egg quality of induced two different molting programs on layer hens. The hons were randomly divided into live groups designated as l, unmolted controls (CON); 2 , molted with feed withdrawal for 10 days (FAST); 3, with feed withdrawa! for 10 days molted and vitamin E supplemented diet $(200 \mathrm{mg} / \mathrm{kg})$ after I 1 days (FAST +VE); 4, layer ration containing $\% 0.08$ sodium for 41 day ( $\mathrm{Lo} \mathrm{Na}$ ); 5 , layer ration containing $\% 0.08$ sodium for 41 day and vitamin E supplemented diet (200 $\mathrm{mg} / \mathrm{kg}$ ) (Lo Na+VE). Water was provided adlibitum consumption for all groups. The photoperiod was reduced to $7 \mathrm{~h} / \mathrm{d}$ for molting and it was raised to $17 \mathrm{~h}$ of light/day after molting. Comparing with the control values in the molting period, serum calcium and phosphorus concentrations of treated groups were significantly decreased $(\mathrm{p}<0.05)$. As a comparison with the control group in the post-molt period, there was an improvement in the eggshell weight and haugh unit in the all treated groups. There were statistically significant increases in the averages of the eggs specific gravity of the Lo $\mathrm{Na}$ and Lo Na+VE groups. Results suggested that supplementing vitamin $E$ to diet of molted laying hens may be has a beneficial effect on egg production and eggshell thickness and haugh unit.

Key words: Vitamin E, forced moll, layers, egg production, egg quality. 


\section{INDRODUCTION}

Forced molting of caged layers is used as a managemont technique to stop egg production in breeding hens for the purpose of recycling them for another season of egg production. There are several types of induced molting methods used today in the commercial egg industry. Prolonged food withdrawal is the most commonly used method of forced molting. The most effective proposed alternative molting techniques are insufficient dietary sodium (Monsi and Enos, 1977; Ross and Herrick, 1981; Naber et al., 1984) and feeding high levels of zinc, (Berry and Brake, 1987; Alodan and Mashaly, 1999). Some researchers obtained results with low $\mathrm{Na}$ ncarly as eflicient as the fasting methods (Nesbeth et al., 1976; Monsi and Enos, 1977). But in the case of Ross and Herrick, (1981) cessation of laying was incomplete and poorer performance from hens on a lo $\mathrm{Na}$ diet was obtained. However, recent research have shown that induced molting significantly depressed the cellular immune response and increased the severity of a concurrent Salmonella enteritidis infections (Holt et al, 1994; Holt and Porter, 1995). Also, Hoshino et al. (1988) reported that fasting is a potent stressor imposed upon the hen. According to Hoshino et al. (1988) the hen might respond to it with a sharp rise in plasma corticosterone levels. Increases in plasma levels of adrenocortical hormone corticosterone, have been reported to be an indicator of acut stress in poultry (Beuving and Vonder, 1978). Tengerdy (1989) suggested that vitamin E supplementation is very effective for animals because vitamin $\mathrm{E}$ can reduce the negative effects of corticosterone induced by stress. Other studies have shown that dietary vitamin $\mathrm{E}$ tends to maintain or increase egg production in chickens (Scheideler and Fonning, 1996; Saunder and Hlachowsky 2001). Heinzerling et al., 1974) reported that chickens fed a diet supplemented with 250 and $300 \mathrm{mg}$ of vitamin $\mathrm{E} / \mathrm{kg}$ increased protection against a moderate E coli infection.

A lack of published data exists concerning the use of vitamin $F$ on production performance and eggshell quality of molted laying hens. Therefore, the objective of the present study is to compare the reproductive performance egg quality of hens during and after molting induced fasting and low sodium diet with supplemented vitamin $E$.

\section{MATERIALS and METHODS}

Experimental layers consisted of 120 Isabrown hens that were 72 wh of age at the beginning of the pre-molt periods. The hens were randomly divided into two rooms (control and four experimental 
groups). In each room, six replicate groups of 24 hens were assigned. Hens were housed two per cages $(24 \times 41 \times 45)$ and received $17 \mathrm{~h}$ of light and $7 \mathrm{~h}$ of darkness/d. Feed and water were provided for adlibitum consumption prior to the beginning of the experiment. The four molting programs were used to compare their effects on egg quality and production. The heris were randomly divided into five treated groups of 24 hens. The hens in the first treatment group (FAST) were fed withdrawn for 10 days and water was provided adlibitum. The photoperiod was reduced to $7 \mathrm{~h} / \mathrm{d}$. At day 11 , hen fed pullet grower ration adlibitum until day 41 and at day 42 hens were returned to a full feed layer ration and received $17 \mathrm{~h}$ of light/day. In the second group (FAST+VE), the hens were fed withdrawn for 10 days and water was provided for adlibitum consumption. The photoperiod was reduced to $7 \mathrm{~h} / \mathrm{d}$. At day 11 , hens were fed pullet grower ration adlibitum until day 42 and the ration was supplemented with $200 \mathrm{mg} / \mathrm{kg}$ vitamin E. At day 42 hens were returned to a full feed layer ration and supplemented with $200 \mathrm{mg} / \mathrm{kg}$ vitamin $\mathrm{E}$. and received $17 \mathrm{~h}$ of light/day. In the third group (Lo Na) were fed layer ration containing $\% 0.08$ sodium for 41 days and water was provided adlibitum. The photoperiod was reduced to $7 \mathrm{~h} / \mathrm{d}$. At day 42 hens were returned to a full feed layer ration and received $17 \mathrm{~h}$ of light/day. In the fourth group (Lo Na+VE) the hens were fed layer ration containing $\% 0.08$ sodium for 41 days and supplemented with $200 \mathrm{mg} / \mathrm{kg}$ vitamin E. Water was provided adlibitum consumption. At day 42 hens were returned to a full feed layer ration + vitamin E $(200 \mathrm{mg} / \mathrm{kg})$ and received $17 \mathrm{~h}$ of light/day. The last group served as a control (CON).

Egg production and mortality were recorded daily while body weight was recorded weekly. Egg weight, shell weight, shell thickness, specific gravity, and haugh unit analysis were also determined, Egg quality measurements made on the same days when the blood samples were taken.

Blood samples were taken during pre-molt, at days 5 and 10 during the molting period, and at days 20 and 60 during the post-molting period in FAST and FAST+VE groups. Other groups' (Lo Na and Lo $\mathrm{Na}+\mathrm{VE}$ ) samples were taken during pre-molt, at days 21 and 42 during the molting period, and at days 20 and 60 prior of the post-molting period. Blood samples were obtained from the brachial vein for determinations levels of vitamin $\mathrm{E}$ calcium and ingoranic phophorus concentrations in plasma. Blood plasma calcium and phosphorus concentrations were determined spectrophotometrically by plasma reagent kits (Sigma Chemical Co.). 


\section{Vitamin E Analysis:}

The level of vitamin $E$ in blood plasma was determined by a method of Rizzo et al. (2000). A mixture of $1 \mathrm{ml}$ plasma, $3 \mathrm{ml}$ absolute ethanol, and $1 \mathrm{ml}$ hexane (HPLC grade) was vortexed and centrifuged to obtain the hexane layer containing the extracted sample. The sample extracted in the hexame layer was injected into the HPLC to determine vitamin $\mathrm{E}$ concentrations.

\section{Statistical Analysis:}

All statistical analyses were carried out using the SPSS statistical analysis software. To determine the effect of Vitamin $\mathrm{E}$ on calcium and inorganic phosphor concentrations in plasma and egg quality parameters, one-way ANOVA were conducted for each group. The average values cbtained of the groups were analysed by using Duncan's test. The results were considered significant if $p<0.05$. All data were expressed as the mean + SEM

\section{RESULTS}

The results presented in Tables $(1 \& 2)$ indicated that supplementation the diet of the feed restricted group (FAST) with vit. E decreased its plasma level in the molting period while the level was significantly increased in the postmolt.

Supplementation the low sodium diet with vit.E significantly increased its level in both molt and postmolt periods.

The results of Tables $(1 \& 2)$ also indicated that plasma calcium and inorganic phosphorus exhibited a similar significant decrease in all the treated groups compared with the control one during the forced molt.

In forced molting period, body weight loss occurred. The results of body weight loss at day 10 was 23.35 and $24.66 \%$ respectively in FAST and FAST+VE, and at day 41 was 11.69 and $12.63 \%$ respectively in Lo Na and Lo Na+VE. The highest body weight loss was recorded in groups FAST+VE. After re-feeding hens on layer diet body weights were increased and became normal.

The mortality rate of fast group was $29 \%$, at the end of day 10 after the feed withdrawal. It was $12.5 \%$ in FAST+VE at the end of 10 day ; $40 \%$ in Lo Na and $8.3 \%$ in Lo Na +VE.

Table 3 shows the results of egg production. Complete egg cessation was materialized at day 8 in FAST and at day 7 in FAST+VE. Although complete egg cessation was not materialized in low sodium diet treatnient, egg production seriously decreased. 
Table 4 shows the effect of feed withdrawal on egg weight, egg specific gravity, shell thickness, shell weight and haugh unit. Table 5 shows the effect of LoNa and LoNa+VE diet on egg weight, egg specific gravity, shell thickness, shell weight and haugh unit.

\section{DISCUSSION}

The experiment reported here was conducted to compare between the effect of low sodium diet and feed restriction procedure for forcing molt in hens. The effect of dietary vitamin $\mathrm{E}$ supplementation on performance and egg quality of different induced molting methods of laying hens were also examined. Molt and postmolt performance data for hens in the five treated groups (CON, FAST, FAST+VE, Lo Na and Lo Na+VE) were reported.

The data of Table (1) cleared that fasting of hens for forcing molt caused an increase in the level of vit.E in blood plasma during molt and post-molt periods compared with the control group, while supplementing the diet with vit.E slightly decreased its level during the molt period and increased significantly $(p<0.05)$ the level in the postmolt.

The results presented in Table (2) showed that feeding the low sodium diet for hens caused an increase in the plasma vit.E level during molt and post-molt periods, while supplementing the dliet with vit.E increased significantly $(p<0.05)$ its level in plasma during both periods of molt and post-molt.

Plasma total calcium and plasma inorganic phosphate exhibited a similar significant decrease in the all treatment (FAST, FAST+VE, Lo $\mathrm{Na}$ and Lo Na+VE) groups during the forced molt (Tables $1 \& 2$ ). The levels of plasma $\mathrm{Ca}$ and $\mathrm{Pi}$ were in the normal levels during both preand post-molt egg production. These findings are in agreement with those of Brake and Thaxton, 1979; Garlich et al. 1984; Turkmen and Mengi, 1994).

In the present study body weight loss shows great differences among the treated groups. The percent of body weight loss was 23.33 in FAST and 24.66 in FAST+VE. In low sodium diet group, the percentage was even less, it was $11.69 \%$ in Lo $\mathrm{Na}$ and 12.63 in Lo Na +VE. The loss of body weight was depending on the feed withdrawal. Baker et al. (1983) suggested there are close relationship between post-molt performance and body weight reduction during the molting period. But Rolon (1993) claims there are no relationships between these two. Sincc there is a relationship between body weight loss and involution of the reproductive tract, post-molt performance might improve (Decuypere 
and Verheyen, 1986; Brake 1992; Zmmermann et al., 1987). But in the present study, the rate of ege production was not significantly improved by molting treatments when compared with the control group (Table 3) Since the post-molting period was limited to 6 weeks in this study, this was the reason of not being able to determine the egg peak. The highest hen-day egg production was $55,91 \%$ in the FAST+VE. group. Another possible reason for improved egg production is the length of egg production cessation period. Some researchers suggested that the longer the cessation period, the better the post-molt production (Buhr and Cunningham, 1994).

In the present study fast treatment effectively induced a complete cessation of lay during the molting phase. Although egg production decreased in the Lo Na group, there was no complete cessation. The extent of cessation of lay during the molt phase and improvement in post-molt production was greatly due to the quantity of sodium in dietary (Naber et al., 1984; Said et al., 1984; Berry and Brake, 1987).

Shell weight and thickness increased in FAST and FAST+VE in post-molting compared to pre-molting. Post-molting haugh units and shell weight were also higher in FAST and FAST+VE when compared with the control. These findings are in agreement with those of Garlich et al. (1984), Christmas et al. (1985), Berry and Brake (1987) and Koelkebeck et al. (1992). Post-molting gravity and haugh unit were higher in Lo Na and Lo Na+VE when compared with the control. These values are statistically significant $(\mathrm{p}<0.05)$ and are in agreement with the finding of some researchers (Naber et al., 1984; Berry and Brake, 1987).

In conclusion, feed withdrawal provided complete egg cessation and higher body weight loss but the rate of mortality was higher than low sodium diet treatment. When these two methods were compared in respect to production and egg quality, no signilicant differences were found. That is why low sodium dietary treatment can be preferred in order to improve the welfare of hens. However, supplemented vitamin $\mathrm{E}$ contributed to the quality of egg and production in both methods. The dietary supplementation of vitamin $E$ for layer hens may be beneficial in reducing the negative effect of stress induced by molting.

\section{REFERENCES}

Alodan, M.A. and Mashaly, M.M. (1999): Effect of induced molting laying hens on production and immune parameters. Poult. Sci. $78: 171-177$ 
Baker, M. Brake, J. and Daniel, Mc. (1983): The relationship between body weight loss during an induced moult and post moult egg production, egg weight and shell quality in caged layers. Poult. Sci.,62: 409-413.

Berry, W.D. and Brake, J. (I987): Postmolt performance of laying hens molted by high dietary zinc, low dietary sodium, and fasting: egg production and eggshell quality. Poult. Sci, $66: 218-226$.

Beuving, G. and Vonder, G.M.A. (1978): Effects of stressing factors on corticosterone levels in the plasma of laying hens. Gen. Comp. Endocrinol. 35:153-159

Brake, J. and Thaxton, T.P. (1979): Physiological changes in caged layers during a forced molt. 2- Gross changes in organs. Poult. Sci. 58: $707-716$

Brake, J.T. (1992): Mechanisms of and metabolic requirements for complete and rapid reproductive rejuvenation during an induced molt-a brief review. Ornis. Scand. 23:335-339.

Buhr, R.J. and Cunningham, D.L. (1994): Evaluation of molt induction to body weight loss of fifteen, twenty, or twenty-five percent by feed removal, daily limited, or alternate-day feeding of a molt feed. Poult.Sci. 73:1499-1510.

Christmas, R.B.: Harms, R.H. and Junqueira, O.M. (1985): Performances of single comb White Leghorn hens subjected to 4 or 10-day feed withdrawal force rest procedures. Poult. Sci. 64 : 2321-2324

Decuypere, E. and Verheyen, (i. (1986): Physiological basis of induced molting and tissue regeneration in fowls. Poult. Sci. 42: 56-68.

Garlich, J.D.; Brake, J.; Parhust, C.R.; Thaxton, J.P. and Morgan, G.W (1984): Physiological profile of caged layers during on production year molt and postmolt:igg production, egg shell quality, liver, femur and blood parameters. Poult, Sci. $63 ; 339$. 343.

Heinzerling, R.H.: Nockels, C.F.: Quales, C.L. and Tengerdy, R.P. (1974): Protection of chicks against E.coli infection by dietary suplementation with vitamin E. Proc. Soc. Exp. Biol. Med. 146: 279-283. of a previous salmonella enteritis infection. Poult. Sci. 72:2069-78.

Holt, P.S and Porter, R.E. (1995): Effect of induced molting on the recurrence of a previous salmonella enteritis infection, Poult. Sci. 72: 2069-78. 
Holt, P.S.: Buhr. R.J.; Cunnigham, D.L. and Porter, R.E. (199.4); Effect of different molting procedures on a salmonella enteritis infection Poult.Sci.73: 1267-75

Hoshino.S: Suzzuki. M.: Kakegawa, T: Imail, K.; Wakita. M. Kobayashi, Y. And Yamada, Y.C. (1988): Changes in plasma thyroid hormones, luteinizing hormone. estradiol, progesterone and corticosterone of laying hens during a forced molt. Comp. Biochem. Physiol. 90A: 355-359.

Koelkebeck, K.W. Parsons, C.M. Leeper. R.W. and Monshtaghan. J (1992): Effect of duration of fasting on postmolt laying hen performance. Poult.Sci; $71: 434-439$

Monsi, A. and Enos H.L. (1977): The effects of low dietary salt on egg production. Poult.Sci. 56:1373-1380.

Naher, E.C., Latshaw, J.D. and Marsh. G.A. (1984): Effectiveness of low sodium diets for recycling of egg production type hens. Poultry.Sci.63:2419-29

Nesbeth, W.G.; Douglas, C.R. and Harms, R.H. (1976): The potential use of dietary salt deficiency for the force resting of laying hens. Poult. Sci. 55:2375-2379.

Rizzo, C.; C.Dionisi-Vici, M.D'lppoliti, F.Fina, G.Sabetta, G.Federici (2000): A simple and rapid HPLC method for simultaneous determination of plasma 7-dehydrocholesterol and vitamin- $\mathrm{E}$ its application in Smith-Lemli-Opitz patients. Clinica Chimica Acta. 291: 97-102.

Rolon, A.; Buhr, R.J. and Cunmgham, D.L. (1993): Twenty-four-hour feed withdrawal and limited feeding as alternative methods for induction of molt in laying hens. Poult.Sci.72:776-785.

Ross, E. and Herrick, R.B. (1981): Forced rest induced by molt or low salt diet and subsequent hen performance. Poult.Sci. 60:63-67.

Said, N.; Sullvan,W.; Bird, H.R. and Sunde, M.L. (1984). A comparision of the effect of two forced molting methods on performance of two commercial strains of laying hens. Poult Sci: $63: 2399-2403$

Saunder, A., and Flachowsky, G. (2001): Influence of high vitamin E dosages on retinal and carotinoid concentration in body tissues and eggs of laying hens. Arch. Tieremahr.55 (1): 43-52.

Scheideler, S.E., and Fonning, G.W. (1996): The combined influence of dietary flaxseed variety, level, form, and storage conditions on egg production and composition among vitamin Esupplemented hens. Poult. Sci.75: 1221-1226 
Tengerdy, R.P. (1989): Vitamin E, immune response, and discase resistance. Ann. NY. Acad. Sci. 570:335-344.

Zimmermann, N.G.; Andrews, D.K. and Ginnis, J. MC. (1987). Comparison of several induced molting methods on subsequent performance of single comb white leghom hens. Poult.Sci. $66: 408-417$

Table 1. Lffect of dictary vitarsin $\mathrm{E}$ on plasma vitamin $\mathrm{E}$, calcium and inorganic phospharus during pre-molt, roit, post-molt in CON. FAST and FAST $+V E$ groups.

\begin{tabular}{|c|c|c|c|c|c|c|}
\hline Parameters & Groups & Pre-molt & Molting (1) & Moiting (2) & Post-molt (1) & Post-moit (2) \\
\hline \multirow{3}{*}{$\begin{array}{l}\text { Vicursin E: } \\
\text { (ng/nl) }\end{array}$} & CON & $13.10+3.21$ & $11.35 \pm 2.63$ & $8.98 \pm 1.94^{6}$ & $10.58 \div 3.99^{\circ}$ & $7.08=3.18^{\circ}$ \\
\hline & FAST & $9.14 \pm 4.03$ & $13.51 \pm 8.86$ & $17.59 \pm 8.42^{3}$ & $14.20+6.92^{8}$ & $20.94 \pm 5.93^{6}$ \\
\hline & FASI+VE & $9.42 \pm 4.03$ & $7.29 \pm 1.65$ & $16.21 \pm 7.17^{\mathrm{a}}$ & $52.08+22.97^{9}$ & $71.76 \pm 11.10^{2}$ \\
\hline \multirow{3}{*}{$\begin{array}{l}\text { Calcitum } \\
\text { \{mg/dl\}) }\end{array}$} & $\operatorname{coN}$ & $25.94 \pm 3.15^{\circ}$ & $27+2.54^{3}$ & $25.56 \div 2.16^{4}$ & $260712.08^{3}$ & $24.45 \div 2.97^{k}$ \\
\hline & EAST & $24.1 \pm 3.10^{*}$ & $11.2+1.5^{6}$ & $9.19 \pm 3.58^{\circ}$ & $15.62 \pm 1.36^{8}$ & $23.72+3^{6}$ \\
\hline & EAST-VE & $26.93 \pm 3.15^{\circ}$ & $9.74+1.27^{6}$ & $8.16 \pm 1.98^{5}$ & $15.15 .11 .1^{\circ}$ & $24.79+2.16^{x}$ \\
\hline \multirow{3}{*}{$\begin{array}{l}\text { horganic } \\
\text { phosphorus } \\
\text { (my'dal) }\end{array}$} & CON & $5.8 \div 0.77^{\mathrm{a}}$ & $3.99 \pm 0.59^{a}$ & $5.52 \pm 0.61^{3}$ & $5.74+0.45^{3 \mathrm{~B}}$ & $5.46=0.54^{x}$ \\
\hline & EAST & $5.35=0.64^{x}$ & $5.24 \pm 0.7 i^{6}$ & $3.73 \pm 0.8^{8}$ & $4.99+0.98^{\mathrm{c}}$ & $5.89=1.24^{7}$ \\
\hline & FAST+VE & $5.74 \pm 0.6^{\circ}$ & $4.67+0.78^{6}$ & $3.63 \pm 0.58$ & $5.08 \pm 1.06^{*}$ & $6.6 \pm 2.06^{2}$ \\
\hline
\end{tabular}

${ }^{*}$ he In cach column within each group. the differences betwern any two means with different Jeters are significantly different ( $(<0.05$ ).

Table 2: Fffect of dietary vitamin E on plasma vitamin E. calcium and inorganic phosphorus during pre-molx, molt, Post-molt in CON. L.o Na and Lo Na+VE groups.

\begin{tabular}{|c|c|c|c|c|c|c|}
\hline P'aramaters & Group & Pre-molt & Molting (1) & Molling (2) & Post-molt (1) & Post-molt (2) \\
\hline \multirow{3}{*}{$\begin{array}{l}\text { Vitamin E } \\
\text { (Hgiml) }\end{array}$} & CON & $11.57 \pm 7.27$ & $7.74 \pm 2.98^{\mathrm{K}}$ & $8.41 \div 3.34$ & $8.52 \pm 3.56^{\mathrm{C}}$ & $8.50+4.31^{5}$ \\
\hline & Lo Na & 9.1414 .03 & $8.39 \pm 1.94^{\circ}$ & $11.28 \pm 5.18$ & $17.08=5.18^{\mathrm{k}}$ & $16.58+8.64^{b}$ \\
\hline & In NalVE & $10.34 \pm 4.93$ & $29.53 \pm 16.47^{5}$ & $13.30+4.80$ & $23.99 \pm 16.44^{\mathrm{a}}$ & $33.44 \pm 23.16^{2}$ \\
\hline \multirow{3}{*}{$\begin{array}{l}\text { (alcium } \\
\text { (mg/di) }\end{array}$} & $\operatorname{coN}$ & $25.94 \pm 3.15^{3}$ & 27.0 & 26.3 & $24.98 \pm 1.46^{3}$ & $25.93 \pm 1.9 \mathrm{I}^{2}$ \\
\hline & Lo Na & $24.113 .1^{9}$ & $14.5 \pm 0.69^{6}$ & $12.25 \pm 4.5^{b}$ & $20.1 \pm 3.19^{\mathrm{h}}$ & $24.02+2^{n}$ \\
\hline & Lo NatVE & $26.93 \times 3.15^{9}$ & $14.07 \pm 1.15^{6}$ & $10.89 \pm 2.53^{\circ}$ & $19.0253 .1^{0}$ & $25.78 \pm 1^{3}$ \\
\hline \multirow{3}{*}{$\begin{array}{l}\text { Dnorganic } \\
\text { plusphorus } \\
\text { (mg/d!) }\end{array}$} & $\operatorname{coN}$ & $5.8 \pm 0.77^{9}$ & $5.86 \pm 0.52^{\mathrm{a}}$ & $5.67+0.76^{7}$ & $5.37 \pm 0.94^{8}$ & $5.37=$ \\
\hline & Lo Nas & $5.35 \pm 0.64^{8}$ & $4.54 \pm 0.69^{b}$ & $4.87=0.75^{6}$ & $4.77 \pm 0.85^{3}$ & $4.7 \tau \pm 0.53^{\pi}$ \\
\hline & Lo Na+VIE & $5.74 \pm 0.6^{\mathrm{a}}$ & $4.12 \pm 1.06^{5}$ & $2.97+0.51 \mathrm{c}$ & $4.58 \pm 1.09^{8}$ & $4.58 \div 1^{2}$ \\
\hline
\end{tabular}

s.lus In each colunu within cach group, differences between any two means with different lerters are significanily ditlerent $(\mathrm{P}<0.05)$. 
Assiut Vet. Med. J. Vol. 50 No. 101 April 2004

Table 3: Hiffect of fout force molting proveciures on her-day egs production dufing premolt moh Postmolt

\begin{tabular}{|c|c|c|c|c|c|}
\hline Poriods & $\mathrm{CON}$ & FASI Grouo & HAS1+VE Group & Lo $\mathrm{Na}$ Grolip & Lo $\mathrm{Na}+\mathrm{Vl}$ Grisul \\
\hline $\begin{array}{l}\text { Pre-molt } \\
\text { (21 davs) }\end{array}$ & $\% 47.2$ & $\% 50.7$ & $\% 48$ & $\% 50,47$ & $\%, 47,91$ \\
\hline $\begin{array}{c}\text { Molting } \\
(1-42 \text { days })\end{array}$ & $\% .56 .30$ & $\% 12.31$ & $\% 12.78$ & $\% 34.80$ & $\% 39.82$ \\
\hline $\begin{array}{l}\text { Post-mols } \\
\text { (42 Unys) }\end{array}$ & $\% 54,36$ & $\% 53.83$ & $\% 55.91$ & $\% 40.53$ & $\% 43.56$ \\
\hline
\end{tabular}

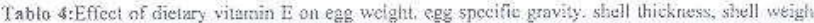
and haugh unith during pre-moll mol. Post-moit in CON, IAST and FAST-VE grours.

\begin{tabular}{|c|c|c|c|c|c|c|}
\hline Parameters & Groups & Fremolt & Molting (1) & Moltiag (2). & Pustarofit (1) & Pastimoli (2) \\
\hline \multirow{3}{*}{ Egg Weight (g) } & & $69.49 \pm 6.15$ & $63=6.04$ & $59 \pm 4.3$ & $66.82 \pm 4.88$ & $68.54+8.72$ \\
\hline & FAST & $70.33+8.75$ & & $66.46 \div 6.92$ & $65.69+5.12$ & $65.97+9.43$ \\
\hline & FAST+VE & $68.08 \pm 6.15$ & $67.35 \pm 2.32$ & $70.02-7.03$ & $60.30 \pm 7.93$ & 66.8018 .74 \\
\hline \multirow{3}{*}{$\begin{array}{l}\text { Figg specific. } \\
\text { gravity }\end{array}$} & & ai) & 02 & 03 & $0630 \pm 0.002$ & $.0612+0.605$ \\
\hline & FAS & $1.06 \%$ & 1.00 & $1.0632 \pm 0.001$ & 1.0 & $5+0.003$ \\
\hline & FAST - & $1.0720 \pm 0.001$ & 1.0645. & $1.0665=0.001$ & $1.0664+0.001$ & 1.063710 .003 \\
\hline \multirow{3}{*}{ Shell Woight (g) } & & & & & 5.1 & $5.81+1.08^{h}$ \\
\hline & & & $\frac{1}{4.6}$ & $5.5010 .07^{5}$ & $6.01 \pm 1.21^{3}$ & $6.11+1.13=$ \\
\hline & F SST +VE & $5.79=0.44$ & $5.47 \pm 1.08^{7}$ & $5.58+1.06^{8}$ & $6.25+1.33^{\circ}$ & $6.66 \pm 0.54^{x}$ \\
\hline \multirow{3}{*}{$\begin{array}{l}\text { Siell thickncss } \\
\text { (rmm) }\end{array}$} & $\operatorname{coN}$ & $0, \overline{36310,0006}$ & $0.363+0.0052$ & $0.370=0.0038$ & $0.371 \pm 0.0028^{\circ}$ & $0.373+16$ \\
\hline & FAST & 0.37510 .0037 & $0.340+0.00 \div 2$ & 0.35540 .0016 & $0.338 \pm 0.0012^{16}$ & $0.370 \div 0.0022$ \\
\hline & FAST+VE & $0.358 \pm 0.0032$ & .0 .34 & 0.34610 .0015 & $0.371 \div 0.0$ & 0.38 \\
\hline \multirow{3}{*}{ Haugh unit } & & $671^{2}+3$ & 1702. & $\mathrm{~F}$ & 1685.52 & $645+0,04$ \\
\hline & 180 & $\frac{7.2 \pm 0}{71.6+0}$ & $\frac{71.3 \pm 0.14}{7.14}$ & $62,4 \leq 0.14^{b}$ & $\frac{18.5 \pm 0.10}{68.2+0.08}$ & $68.2 \div 0.00^{\circ}$ \\
\hline & FAST & $60,1+0.12$ & $72 \leq 10.12$ & $71.1 \pm 0.10^{2}$ & $70.3 \div 0.31$ & $70.1 \pm 0.03^{\prime}$ \\
\hline
\end{tabular}

ahe In cach colurns within eacis group, the differencos wetween the means with different letces are signiffenativ different $(P<0.05)$.

Table 5: Eftect of dictary vitamiz E on cge wcight. eng specific gravily. shell weight. shell thickness, and haugin mit, during pre-molc molt. Post-moll in CON. Lo Na and $1.0 \mathrm{Na}$-VE, groups

\begin{tabular}{|c|c|c|c|c|c|c|}
\hline Parameters & Grougs & Eremolt & Molling (1) & Moling (2) & Posmoli (1) & Postmoli (2) \\
\hline Ege weight (g) & 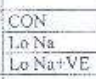 & $\begin{array}{l}69.44 \pm 6.03 \\
71.61+8.07 \\
70.49+7.56\end{array}$ & 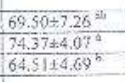 & $\begin{array}{l}\frac{69.50 \leq 7.90^{26}}{71.85+6.87^{3}} \\
65.48 \pm 5.25^{6}\end{array}$ & $\frac{68.64+9.72}{68.64-9.72}$ & \begin{tabular}{|l}
$68.772 .10^{6}$ \\
$72.76+1.07^{7}$ \\
$71.90 \pm 1.90^{2}$
\end{tabular} \\
\hline $\begin{array}{c}\text { Ege specific. } \\
\text { gravity }\end{array}$ & $\begin{array}{l}\text { LoNa } \\
\text { LoNatVE }\end{array}$ & $\frac{\frac{1.0637 \pm 0.001}{1.0639+0.00 !}}{1.0637 \times 0.003}$ & $\begin{array}{l}1.0644=0.002^{5} \\
\frac{1.0695 \pm 0.003^{3}}{1.0623 \pm 0.002^{3}}\end{array}$ & $\begin{array}{l}1.0626=0.002^{6} \\
1.068600 .001^{7} \\
1.0630+0.003^{h}\end{array}$ & $\begin{array}{l}1.062000 .003^{5} \\
1.006200 .00^{2} \\
1.066210 .003^{6}\end{array}$ & $\begin{array}{l}\frac{1.0632+0.001^{2}}{1.0710+0.062^{*}} \\
1.09420 .002^{*}\end{array}$ \\
\hline Shell we ight $(g)$ & $\begin{array}{l}\frac{C O N}{10 N a} \\
\frac{10 N a+V E}{L}\end{array}$ & $\frac{\frac{5.98 \pm 1.24}{3.90 \leq 1.31}}{5.81 \pm 1.33}$ & $\begin{array}{l}5.73 \pm 0.72 \\
5.89 \div 1.04 \\
5.24+1.22\end{array}$ & $\frac{6.0110 .85}{6.02 \pm 0.87}$ & $\begin{array}{l}\frac{5.84 \pm 0.50^{3}}{6.36+50.71} \\
6.16+0.98\end{array}$ & $\begin{array}{l}5.97+1.32 \\
6.41=1.08^{1} \\
6.43 .081^{1}\end{array}$ \\
\hline $\begin{array}{l}\text { Shell thickness } \\
\text { (mm) }\end{array}$ & $\begin{array}{l}\text { CON } \\
\text { LoNa } \\
\text { LoNatre }\end{array}$ & $\begin{array}{l}0.37710 .0043 \\
0.381+0.0033 \\
0.371 \pm 0.0049\end{array}$ & $\begin{array}{l}0.381+0.0023^{*} \\
0.35700 .0011^{*} \\
0.361-0.0024^{*}\end{array}$ & $\begin{array}{l}0.36610 .0034 \\
0.387+0.0028 \\
0.398 \pm 0.0052\end{array}$ & $\begin{array}{l}0.369+0.0059 \\
0.388 \pm 0.0018 \\
0.379 \pm 0.0017\end{array}$ & 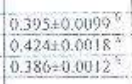 \\
\hline Haugh uni! & $\frac{\mathrm{CON}}{1.0 \mathrm{Na}_{a}} \frac{\mathrm{L} 0 \mathrm{Na}+\mathrm{VE}}{}$ & $\begin{array}{l}68.2 \pm 0.12 \\
69,3=0.12 \\
69.7 \pm 0.13\end{array}$ & $\begin{array}{l}67.4 \pm 0.07 \\
67.5 \div 0.09 \\
68.5 \div 0.06\end{array}$ & $\frac{\frac{65.8 \pm 0.14^{6}}{62.8 \pm 0.11^{6}}}{69.3 \pm 0.11^{8}}$ & $\frac{66.410 .04}{\frac{68.3+0.03}{69.7 \pm 0.01}}$ & $\begin{array}{l}67.1+0.10^{3} \\
68.7 \div 0.12^{+} \\
70.2200 .08^{3}\end{array}$ \\
\hline
\end{tabular}

tbe In each column within each group, differences between any two means with differeat letters are significantly different (P<0.05). 